\title{
PENGARUH PAD DAN DANA PERIMBANGAN TERHADAP KINERJA KEUANGAN PEMERINTAH DAERAH DI WILAYAH SARBAGITA PROVINSI BALI
}

\author{
Ni Kadek Novia Indrawati Putri ${ }^{1}$ \\ Ni Putu Ayu Darmayanti \\ ${ }^{1}$ Fakultas Ekonomi dan Bisnis Universitas Udayana (Unud), Bali, Indonesia \\ E-mail:noviaindrawatii@yahoo.com
}

\begin{abstract}
ABSTRAK
Penelitian ini bertujuan untuk mengetahui pengaruh PAD dan dana perimbangan terhadap kinerja keuangan pemerintah daerah. Penelitian ini dilakukan di Kota Denpasar, Kabupaten Badung, Kabupaten Gianyar, dan Kabupaten Tabanan atau sering disebut dengan wilayah Sarbagita.Desain penelitian dalam penelitian ini menggunakan pendekatan asosiatif. Populasi dan sampel dalam penelitian ini adalah pemerintah Kota Denpasar, Kabupaten Badung, Kabupaten Gianyar, dan Kabupaten Tabanan (wilayah Sarbagita) dengan metode penentuan sampel yang digunakan adalah metode sampling jenuh. Pengumpulan data menggunakan metode observasi non partisipan dengan cara observasi pada laporan realisasi APDB pemerintah Kabupaten/Kota di wilayah Sarbagita tahun anggaran 2012-2016 dengan teknik analisis yang digunakan adalah regresi linier berganda. Hasil analisis menunjukkan bahwa PAD dan dana perimbangan berpengaruh negatif signifikan terhadap kinerja keuangan pemerintah daerah. Hasil ini menunjukkan bahwa semakin meningkatnya perolehan PAD dan penerimaan dana perimbangan akan diikuti dengan penurunan kinerja keuangan pemerintah daerah.
\end{abstract}

Kata kunci:pendapatan asli daerah, dana perimbangan, kinerja keuangan pemerintah daerah

\begin{abstract}
This study aims to determine the effect of local revenue and balancing funds on the financial performance of local governments. This research was conducted in Denpasar City, Badung Regency, Gianyar Regency, and Tabanan Regency or often referred to as the Sarbagita area. The research design in this study used an associative approach. The population and sample in this study were Denpasar City Government, Badung Regency, Gianyar Regency, and Tabanan Regency (Sarbagita region) with the method of determining the sample used was a saturated sampling method. Data collection uses the non-participant observation method by observing the realization report of the District / City Government Budget in the Sarbagita region for the 2012-2016 fiscal year with the analysis technique used is multiple linear regression. The results of the analysis show that local revenue and balance funds have a significant negative effect on the financial performance of local governments. These results indicate that the increasing acquisition of local revenue and receipt of balance funds will be followed by a decrease in the financial performance of regional governments.
\end{abstract}

Keywords: local revenue, balance funds, local government financial performance 


\section{PENDAHULUAN}

Provinsi Bali merupakan salah satu dari provinsi yang ada di Indonesia yang menerapkan otonomi daerah. Otonomi daerah memberikan kekuasaan dan kewenangan pemerintah ke daerah dengan desentralisasi pemerintahan sesuai Undang-undang Nomor 22 Tahun 1999 tentang Pemerintah Daerah yang kemudian digantikan oleh Undang-undang Nomor 32 tahun 2004 tentang Pemerintah Daerah untuk mengelola keuangannya sendiri dan dalam mengambil keputusan yang di anggap sesuai dengan kepentingan, sehingga nantinya diharapkan dapat meningkatkan kesejahteraan rakyat. Provinsi Bali menjadikan otonomi daerah sebagai acuan dalam pelaksanaan pelayanan publik yang memiliki tujuan dan arah yang jelas dalam memberikan pelayanan kepada masyarakat.

Otonomi daerah memberikan keleluasaan bagi pemerintah untuk mengelola sumber daya yang dimiliki sesuai dengan kepentingan, prioritas, dan potensi daerah itu sendiri. Menurut Taras dan Artini (2017) pemberian otonomi daerah akan mempengaruhi pertumbuhan ekonomi suatu daerah yang akan memberikan kebebasan kepada pemerintah daerah untuk membuat rencana keuangannya sendiri. Pelaksanaan otonomi daerah sangat memerlukan adanya sistem desentralisasi secara transparan, efektif dan efisien, dan dapat dipertanggung jawabkan kepada masyarakat luas. Rosemarry et al. (2016) mengemukakan bahwa alasan diterapkannya kebijakan otonomi pada daerah karena pemerintah pusat tidak mampu mengurus secara mandiri keberhasilan pembangunan daerah secara keseluruhan oleh sebab itu pemerintah pusat melimpahkan kewenangan 
Ni Kadek Novia Indrawati Putridan Ni Putu Ayu Darmayanti, Pengaruh PAD dan..

ataupun kekuasaan terhadap pemerintah daerah untuk mengatur dan mengurus secara mandiri kepentingan-kepentingan daerahnya.

Penilaian kinerja keuangan pemerintah daerah sangat penting untuk dilakukan karena pemerintah pusat menerapan kebijakan otonomi daerah dengan harapan bahwa pemerintah daerah dapat lebih mandiri dalam mengelola keuangan daerahnya dengan tujuan agar proses pembangunan yang dilakukan daerah dapat diselesaikan dengan cepat tanpa harus menunggu bantuan pendanaan yang bersumber dari pusat (Antari dan Sedana, 2018). Kinerja (performance) diartikan sebagai aktivitas terukur dari suatu entitas selama periode tertentu sebagai bagian dari ukuran pekerjaan. Kinerja bisa diketahui hanya jika individu maupun kelompok individu tersebut mempunyai kriteria keberhasilan yang telah ditetapkan (Mokodompit et al., 2014). Keuangan daerah adalah semua hak dan kewajiban daerah dalam rangka penyelenggaraan pemerintah daerah yang dapat dinilai dengan uang termasuk di dalamnya segala bentuk kekayaan yang berhubungan dengan hak dan kewajiban tersebut dalam rangka APBD (Bab 1, Pasal 1 Ayat 5 Peraturan Pemerintah No. 58 Tahun 2005). Kinerja keuangan pemerintah daerah menunjukkan tingkat pencapaian dari hasil kerja di bidang keuangan daerah yang meliputi penerimaan dan belanja daerah dengan menggunakan sistem keuangan melalui kebijakan atau ketentuan perundangundangan selama satu periode tertentu. Selama periode tersebut, pemerintah diharapkan mampu menghasilkan kinerja yang optimal dengan rancangan anggaran yang telah ditetapkan dan disahkan sebelumnya. 
Pengukuran kinerja keuangan untuk kepentingan publik dapat dijadikan evaluasi dan memulihkan kinerja dengan membandingkan skema kerja dan pelaksanaannya. Kinerja keuangan pemerintah daerah mampu memberikan kontribusi terhadap pertumbuhan pendapatan daerah setiap tahunnya dilihat dari seberapa besar kemampuan pemerintah daerah dalam menggali potensi-potensi daerahnya (Antari dan Sedana, 2018). Peningkatan kinerja keuangan pemerintah akan berdampak pada kesejahteraan masyarakat, dimana semakin besar kemampuan daerah dalam menggali potensi-potensi daerah selain digunakan untuk membiayai jalannya sistem pemerintahan dan pembangunan daerah, juga digunakan untuk meningkatkan pelayanan kepada masyarakat secara optimal.

Menurut Halim (2008:230), alat untuk menganalisis kinerja keuangan pemerintah daerah adalah dengan menerapkan rasio keuangan terhadap APBD. Rasio-rasio tersebut diantaranya diantaranya rasio kemandirian keuangan daerah, rasio efisiensi, rasio pertumbuhan, dan rasio efektivitas. Pengukuran kinerja keuangan pemerintah daerah dalam penelitian ini diukur dengan menggunakan rasio pertumbuhan pendapatan daerah. Rasio pertumbuhan bermanfaat untuk mengetahui apakah pemerintah daerah dalam tahun anggaran bersangkutan atau selama beberapa periode anggaran, kinerja anggarannya mengalami pertumbuhan pendapatan atau belanja secara positif atau negatif (Mahmudi 2010:138).

Kemampuan pemerintah daerah dalam mengelola keuangan tercermin dalam Anggaran Pendapatan dan Belanja Daerah (APBD) yang menggambarkan kemampuan pemerintah daerah dalam membiayai kegiatan pelaksanaan tugas pembangunan, serta pemerataan dan keadilan dengan mengembangkan seluruh 
Ni Kadek Novia Indrawati Putridan Ni Putu Ayu Darmayanti, Pengaruh PAD dan..

potensi yang dimiliki oleh masing-masing daerah (Kamaroellah, 2017) . Pendapatan yang diterima dalam APBD akan digunakan untuk membiayai kebutuhan daerahnya, dan diharapkan pendapatan tersebut akan terus meningkat secara signifikan tiap tahunnya. Penyusunan APBD akan disesuaikan dengan kebutuhan penyelenggaraan pemerintah dan kemampuan keuangan daerah seperti kemampuannya dalam meningkatkan penerimaan pendapatan daerahnya.

Pemerintah daerah sebagai pihak yang berperan dalam mengelola keuangan daerah sangat penting untuk meminimalkan terjadinya penurunan pertumbuhan pendapatan daerah setiap tahunnya dengan meningkatkan kemampuannya dalam menghasilkan sumber-sumber keuangan (Antari dan Sedana, 2018). Tabel 1 berikut menyajikan data mengenai pendapatan daerah Kabupaten/Kota Provinsi Bali Tahun 2012-2016.

\section{Tabel 1.}

Pendapatan Daerah Kabupaten/Kota Provinsi Bali Tahun 2012-2016

\begin{tabular}{lrrrrr}
\hline Kabupaten/ & \multicolumn{5}{c}{ Pendapatan Daerah Kabupaten/Kota (Ribu Rupiah) } \\
Kota & $\mathbf{2 0 1 2}$ & \multicolumn{1}{c}{$\mathbf{2 0 1 3}$} & $\mathbf{2 0 1 4}$ & $\mathbf{2 0 1 5}$ & $\mathbf{2 0 1 6}$ \\
\hline Jembrana & 651.398 .304 & 745.334 .983 & 823.352 .410 & 903.622 .270 & 1.090 .625 .089 \\
Tabanan & 1.056 .319 .329 & 1.253 .026 .819 & 1.367 .078 .412 & 1.615 .933 .308 & 1.794 .601 .450 \\
Badung & 2.618 .695 .201 & 2.954 .662 .971 & 3.459 .986 .016 & 3.735 .129 .565 & 4.328 .245 .676 \\
Gianyar & 1.066 .239 .511 & 1.248 .415 .648 & 1.400 .913 .781 & 1.527 .797 .536 & 1.682 .778 .978 \\
Klungkung & 590.231 .294 & 711.405 .235 & 827.028 .807 & 907.139 .632 & 1.062 .218 .238 \\
Bangli & 622.718 .265 & 702.229 .030 & 793.647 .679 & 873.469 .027 & 1.040 .303 .804 \\
Karangasem & 907.014 .578 & 1.041 .577 .611 & 1.248 .392 .023 & 1.367 .577 .564 & 1.462 .024 .349 \\
Buleleng & 1.196 .436 .251 & 1.390 .657 .293 & 1.543 .584 .631 & 1.937 .771 .345 & 2.066 .173 .156 \\
Denpasar & 1.379 .049 .166 & 1.547 .605 .213 & 1.727 .968 .713 & 1.786 .400 .782 & 1.943 .172 .688 \\
\hline Sumber: Badan Pusat Statistik Provinsi Bali, 2017 & & &
\end{tabular}

Tabel 1 menyajikan data mengenai Pendapatan Daerah Kabupaten/Kota Provinsi Bali pada Tahun 2012-2016. Total pendapatan daerah bersumber dari PAD, dana perimbangan, dan lain-lain pendapatan daerah yang sah. Berdasarkan Tabel 1 menunjukkan bahwa pendapatan daerah di seluruh Kabupaten/Kota Provinsi Bali selalu mengalami peningkatan dari tahun 2012-2016. Pendapatan 
tertinggi diperoleh Kabupaten Badung dan pendapatan terendah diperoleh Kabupaten Bangli.

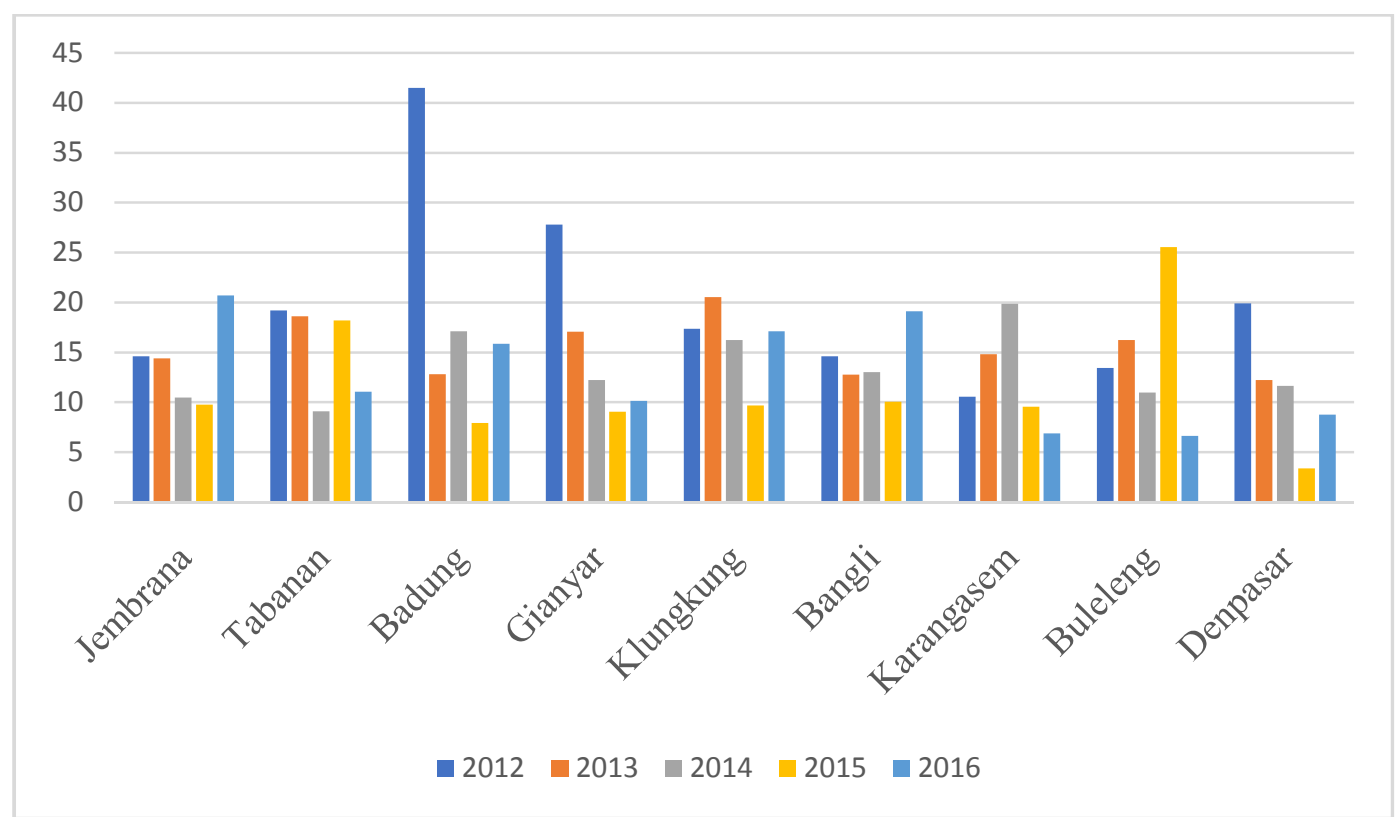

Grafik 1. Pertumbuhan Pendapatan Daerah Kabupaten/Kota Provinsi Bali Tahun 2012-2016

Sumber: Data diolah, 2018

Ditinjau dari segi pertumbuhannya, pendapatan daerah di seluruh Kabupaten/Kota Provinsi Bali dari tahun 2012-2016 cenderung mengalami fluktuasi. Berdasarkan Grafik 1 di atas, dapat diketahui bahwa pertumbuhan pendapatan daerah Kabupaten Badung pada tahun 2013 mengalami penurunan yang cukup tinggi hingga 28,66 persen dibandingkan dengan pertumbuhan pendapatan daerah Kabupaten/Kota Provinsi Bali lainnya sedangkan pertumbuhan pendapatan daerah Kabupaten Buleleng pada tahun 2015 mengalami kenaikan yang cukup tinggi hingga 14,54 persen dibandingkan dengan Kabupaten/Kota Provinsi Bali lainnya.

Suatu daerah dapat dikatakan berhasil apabila pemerintahan daerah tersebut mampu untuk meningkatkan pertumbuhan pendapatannya secara signifikan setiap 
Ni Kadek Novia Indrawati Putridan Ni Putu Ayu Darmayanti, Pengaruh PAD dan..

tahunnya. Sejalan dengan diterapkannya otonomi daerah, maka pemerintahan di Provinsi Bali harus berjalan dengan baik agar dapat dikatakan berhasil. Keberhasilan otonomi daerah tersebut dapat diihat dari PAD, namun kenyataan pemerintah daerah masih sangatbergantung pada dana bantuan pusat yang disebut dana perimbangan (Armaja et al., 2015). PAD dan dana perimbangan memiliki peranan yang besar sebagai sumber pembiayaan pembangunan dan pada akhirnya mampu mendorong pertumbuhan ekonomi di daerah (Yanto et al., 2015).

PAD merupakan salah satu pilar kemandirian suatu daerah yang bersumber dari kegiatan ekonomi daerah itu sendiri. Sumber PAD terdiri dari pajak daerah, retribusi daerah, hasil pengelolaan kekayaan daerah, dan lain-lain PAD yang sah. Kemampuan suatu daerah menggali PAD akan mempengaruhiperkembangan dan pembangunan suatu daerah (Wahyuningsih, 2016). Dana perimbangan juga merupakan salah satu sumber pendanaan daerah. Undang-undang No.33 tahun 2004 menyebutkan bahwa dana perimbangan adalah dana yang bersumber dari pendapatan Anggaran Pendapatan dan Belanja Negara (APBN) yang dialokasikan kepada daerah untuk mendanai kebutuhan daerah dalam rangka pelaksanaan desentralisasi. Era desentralisasi membuat pengawasan keuangan terhadap pemerintah daerah harus dilakukan lebih efektifoleh pemerintah pusat agar tercipta suasana pemerintahan daerah yang transparan danakuntabel (Armaja et al., 2015).

Era reformasi dan pelaksanaan otonomi daerah yang lebih luas mengakibatkan semakin kuatnya tuntutan masyarakat terhadap penyelenggaraan pemerintahan yang baik (Erawati, 2012). Provinsi Bali memiliki 4 Kabupaten 
yang dijadikan sebagai kawasan metropolitan, yaitu Kota Denpasar, Kabupaten Badung, Kabupaten Gianyar, Kabupaten Tabanan yang sering disebut dengan wilayah Sarbagita. Kawasan metropolitan merupakan suatu kawasan dengan konsentrasi penduduk yang besar, dengan kesatuan ekonomi dan sosial yang terpadu, dan mencirikan aktivitas kota. Kawasan metropolitan seringkali berperan sebagai pusat konsentrasi kegiatan yang tinggi sehingga menjadi mesin pertumbuhan wilayah untuk skala regional, nasional, bahkan internasional (Mardianta et al., 2016). Kawasan metropolitan di Bali, diharapkan mampu untuk menjadi penunjang dalam pertumbuhan pendapatan daerah maupun provinsi. Kita tahu sendiri bahwa wilayah Sarbagita memiliki pendapatan yang tinggi dan selalu mengalami peningkatan dari tahun 2012-2016 namun jika ditinjau dari segi pertumbuhannya, pendapatan daerah wilayah Sarbagita tersebut cenderung mengalami fluktuasi pada tahun 2012-2016.

Beberapa penelitian sebelumnya yang meneliti pengaruh PAD terhadap kinerja keuangan pemerintah daerah, mengemukakan perbedaan hasil. Hasil penelitian yang dilakukan Budianto dan Alexander (2016) menunjukkan bahwa semakin besar PAD, semakin baik kinerja keuangan daerah sesuai dengan prinsipprinsip otonomi daerah yang akan mengakibatkan peningkatan kinerja keuangan pemerintah. Darwanis dan Saputra (2014) mengemukakan bahwa pendapatan daerah memiliki peranan penting, karena melalui pendapatan daerah tersebut dapat dilihat sejauh mana suatu daerah dapat membiayai kegiatan pemerintahan dan pembangunan daerah, sehingga pemerintah daerah akan terus-menerus meningkatkan pertumbuhan kinerja keuangannya. Indriani dan Sastradipraja 
Ni Kadek Novia Indrawati Putridan Ni Putu Ayu Darmayanti, Pengaruh PAD dan..

(2014) serta Antari dan Sedana (2018) dalam penelitiannya juga menemukan bahwa PAD berpengaruh positif signifikan terhadap kinerja keuangan pemerintah daerah. Di sisi lain, hasil penelitian yang dilakukan Wiguna (2015) menunjukkan bahwa pemerintah daerah dengan PAD yang besar tidak serta merta dapat meningkatkan kinerja keuangan pemerintah daerah dikarenakan efisiensi keuangan untuk menilai kinerja keuangan pemerintah daerah tersebut masih buruk. Penelitian yang dilakukan Armaja et al. (2015) serta Mulyani dan Wibowo (2017) juga mendapatkan hasil yang sama yaitu PAD berpengaruh negatif signifikan terhadap kinerja keuangan pemerintah daerah.

Dana perimbangan, sebagai variabel bebas dalam penelitian ini, memiliki pengaruh terhadap kinerja keuangan pemerintah daerah. Beberapa penelitian sebelumnya yang meneliti pengaruh dana perimbangan terhadap kinerja keuangan pemerintah daerah juga mengemukakan perbedaan hasil. Hasil penelitian yang dilakukan Aziz (2016) menunjukkan bahwa semakin tinggi dana perimbangan yang diterima suatu daerah maka semakin baik kinerja keuangan pemerintah daerah dikarenakan tersedianya dana yang dapat digunakan untuk membiayai penyelenggaraan pemerintahan dan memberikan pelayanan kepada masyarakat, sehingga dapat dikatakan bahwa dana perimbangan berpengaruh positif signifikan terhadap kinerja keuangan pemerintah daerah. Penelitian yang dilakukan Simanullang (2016) juga menemukan bahwa dana perimbangan berpengaruh positif signifikan terhadap kinerja keuangan pemerintah daerah. Di sisi lain, hasil penelitian yang dilakukan Andirfa et al. (2016) menunjukkan bahwa semakin tinggi dana perimbangan yang diterima dari pemerintah pusat ke pemerintah 
daerah akan memperlihatkan semakin kuat ketergantungan pemerintah daerah dalam memenuhi kebutuhan daerahnya, sehingga kinerja keuangan pemerintah daerah akan menurun. Indriani dan Sastradipraja (2014) mengemukakan bahwa tingginya penerimaan dana perimbangan dari pemerintah pusat berarti pemerintah daerah belum secara optimal menggali potensi-potensi yang dimiliki daerahnya untuk mendapatkan pendapatan yang lebih. Penelitian yang dilakukan Armaja et al. (2015), Wahyuningsih (2016), serta Budianto dan Alexander (2016) juga mendapatkan hasil yang sama yaitu dana perimbangan berpengaruh negatif signifikan terhadap kinerja keuangan pemerintah daerah.

Penelitian ini dilakukan karena masih adanya perbedaan hasil penelitian terdahulu mengenai pengaruh PAD dan dana perimbangan terhadap kinerja keuangan pemerintah daerah. Analisis PAD dan dana perimbangan dilakukan guna melihat seberapa besar pengaruh yang dihasilkan oleh masing-masing variabel terhadap kinerja keuangan pemerintah daerah. Peningkatan kinerja keuangan pemerintah daerahsangat penting dilakukan karena merupakan cerminan keberhasilan pemerintah daerah dalam mengelola keuangan daerah demi kesejahteraan masyarakatnya.

PAD merupakan tulang punggung pembiayaan daerah, karena PAD paling berkontribusi untuk pembangunan daerah dan kesejahteraan masyarakat daerah tersebut. Oleh sebab itu, kemampuan suatu daerah menggali PAD akan mempengaruhi perkembangan dan pembangunan daerah tersebut termasuk wilayah Sarbagita yang notabena menjadi sektor pariwisata di Bali. Semakin besar kontribusi PAD terhadap APBD, maka akan semakin kecil pula 
Ni Kadek Novia Indrawati Putridan Ni Putu Ayu Darmayanti, Pengaruh PAD dan..

ketergantungan terhadap bantuan pemerintah pusat, sehingga semakin tinggi penerimaan PAD akan memaksimalkan pemerintah daerah dalam pembangunan pemerintahan daerah yang berprinsip otonomi daerah yang nantinya akan berdampak pada kinerja keuangan pemerintah daerah yang semakin baik. Pernyataan tersebut sejalan dengan hasil penelitian yang dilakukan oleh Antari (2018) yang menyatakan bahwa peningkatan PAD dapat menyebabkan terjadinya peningkatan kemampuan pemerintah daerah untuk membiayai sendiri segala kegiatan daerahnya sehingga memberikan indikasi bahwa pemerintah daerah telah memiliki kinerja yang baik.

Budianto dan Alexander (2016) mengemukakan bahwa dengan menekankan hasil PAD yang berasal dari berbagai sumber yang dikelola oleh pemerintah daerah dalam bentuk penerimaan pajak, retribusi, dan penerimaan lainnya yang sah yang diatur dalam undang-undang dapat meningkatkan PAD sehingga mengakibatkan peningkatan kinerja keuangan pemerintah. Darwanis dan Saputra (2014), dan Wahyuningsih (2016) juga menyatakan bahwa Pendapatan Asli Daerah berpengaruh positif signifikan terhadap kinerja keuangan pemerintah daerah.

Berdasarkan landasan teori dan hasil penelitian sebelumnya, maka hipotesis penelitian yang dihasilkan adalah sebagai berikut :

$\mathrm{H}_{1}$ : Pendapatan Asli Daerah (PAD) berpengaruh positif signifikan terhadap kinerja keuangan pemerintah daerah.

Dana perimbangan adalah dana yang bersumber dari pendapatan APBN yang dialokasikan kepada daerah untuk mendanai kebutuhan daerahnya dalam rangka pelaksanaan desentralisasi. Dana perimbangan yang meliputi dana bagi 
hasil pajak dan bukan pajak, Dana Alokasi Umum (DAU) dan Dana Alokasi Khusus (DAK) merupakan dana transfer dari pemerintah pusat kepada pemerintah daerah dengan tujuan untuk membiayai kelebihan belanja daerah. Penerimaan dana perimbangan juga mencerminkan kemampuan keuangan dari suatu daerah untuk mengelola keuangan daerah tersebut. Tingginya ketergantungan daerah dengan dana perimbangan yang diterima dari pemerintah pusat atau semakin besarnya dana perimbangan yang diperoleh maka kemampuan keuangan daerah tersebut untuk menggali potensi dari daerahnya sendiri semakin rendah dan kemandirian keuangan juga akan rendah sehingga mengindikasikan kinerja keuangan pemerintah daerah tersebut juga rendah.

Alfarisi (2015) menyatakan bahwa semakin besar dana yang diterima dari pemerintah pusat, maka semakin kuat pemerintah daerah bergantung kepada pemerintah pusat untuk memenuhi kebutuhan daerahnya sehingga mengakibatkan kinerja keuangan pemerintah daerah menurun. Perimbangan antara pemerintah pusat dengan pemerintah daerah dapat dikatakan ideal apabila setiap tingkat pemerintahan dapat mengatur keuangannya untuk membiayai tugas dan wewenang daerahnya masing-masing. Armaja et al.(2015), Andirfa et al.(2016), serta Budianto dan Alexander (2016) juga menyatakan bahwa dana perimbangan berpengaruh negatif signifikan terhadap kinerja keuangan pemerintah daerah.

$\mathrm{H}_{2}$ : Dana Perimbangan berpengaruh negatif signifikan terhadap kinerja keuangan pemerintah daerah.

\section{METODE PENELITIAN}

Lokasi atau ruang lingkup wilayah penelitian ini adalah empat

Kabupaten/Kota Provinsi Bali yaitu Kota Denpasar, Kabupaten Badung, 
Ni Kadek Novia Indrawati Putridan Ni Putu Ayu Darmayanti, Pengaruh PAD dan..

Kabupaten Gianyar, dan Kabupaten Tabanan atau sering disebut dengan wilayah Sarbagita. Variabel terikat dalam penelitian ini adalah kinerja keuangan pemerintah daerah dengan simbol Y. Variabel bebas dalam penelitian ini adalah Pendapatan Asli Daerah (PAD) dengan simbol $\mathrm{X}_{1}$ dan Dana Perimbangan dengan $\operatorname{simbol~} X_{2}$.

Kinerja keuangan pemerintah daerah merupakan suatu pencapaian hasil di bidang keuangan daerah pada pemerintahan Kabupaten/Kota di wilayah Sarbagita Provinsi Bali tahun 2012-2016. Skala pengukuran yang digunakan adalah rasio pertumbuhan dan dinyatakan dalam satuan persentase. Untuk menghitung rasio pertumbuhan, maka dapat digunakan rumus sebagai berikut.

$$
\mathrm{r}=\frac{P-P}{P} \times 100 \%
$$

\footnotetext{
Keterangan :

$r=$ Pertumbuhan (dalam persen)

Pn = Realisasi pendapatan daerah pada tahun ke-n

Po = Realisasi pendapatan daerah pada tahun awal
}

Pendapatan Asli Daerah (PAD) merupakan pendapatan yang diterima pemerin-tahan kabupaten/kota di wilayah Sarbagita Provinsi Bali tahun 20122016. Data yang digunakan dalam penelitian ini adalah data realisasi total Pendapatan Asli Daerah Kota Denpasar, Kabupaten Badung, Kabupaten Gianyar, dan Kabupaten Tabanan pada tahun 2012-2016 yang terdapat dalam laporan realisasi APBD yang dinyatakan dalam bilangan natural. Total pendapatan tersebut diperoleh dari pajak daerah, retribusi daerah, hasil pengelolaan kekayaan daerah yang dipisahkan, serta lain-lain PAD yang sah. 
Dana Perimbangan adalah dana transfer yang bersifat terikat dari pemerintah pusat yang diberikan pemerintahan Kabupaten/Kota di wilayah Sarbagita Provinsi Bali tahun 2012-2016. Data yang digunakan dalam penelitian ini adalah data realisasi total Dana Perimbangan Kota Denpasar, Kabupaten Badung, Kabupaten Gianyar, dan Kabupaten Tabanan pada tahun 2012-2016 laporan realisasi APBD yang dinyatakan dalam bilangan natural. Total dana perimbangan tersebut diperoleh dari dana bagi hasil, dana alokasi umum, dan dana alokasi khusus.

Populasi dan sampel yang digunakan dalam penelitian ini adalah Pemerintah Kota Denpasar, Kabupaten Badung, Kabupaten Gianyar, dan Kabupaten Tabanan (wilayah Sarbagita). Metode penentuan sampel yang digunakan adalah dengan metode sampling jenuh atau sensus, dimana semua anggota populasi dijadikan sampel.

Pengumpulan data dalam penelitian ini menggunakan metode observasi non partisipan, dimana peneliti tidak terlibat langsung dalam penelitian tetapi hanya sebagai pengamat independen yang dilakukan dengan cara observasi pada laporan realisasi APDB pemerintah Kabupaten/Kota Provinsi Bali tahun anggaran 20122016 terutama di wilayah Sarbagita yang dapat diakses melalui situs resmi Badan Pusat Statistik Provinsi Bali.

Analisis regresi linear berganda pada penelitian ini digunakan untuk mengetahui dan menganalisis pengaruh PAD dan dana perimbangan terhadap kinerja keuangan pemerintah daerah di wilayah Sarbagita. Analisis ini juga digunakan untuk memperoleh gambaran mengenai pengaruh PAD dan dana 
Ni Kadek Novia Indrawati Putridan Ni Putu Ayu Darmayanti, Pengaruh PAD dan..

perimbangan terhadap kinerja keuangan pemerintah daerah di wilayah Sarbagita dengan laporan realisasi APBD wilayah tersebut.

Model analisis linear berganda pada penelitian ini dapat di rumuskan dalam persamaan sebagai berikut :

$Y=\alpha+\beta_{1} X_{1}+\beta_{2} X_{2}+\varepsilon_{i}$

Keterangan :

$\mathrm{Y}=$ Kinerja Keuangan Pemerintah Daerah

$u \quad=$ Konstanta Regresi

$\beta_{1} \quad=$ Koefisien Regresi Rasio Pendapatan Asli Daerah (PAD)

$\beta_{2} \quad=$ Koefisien Regresi Dana perimbangan

$X_{1}=$ Pendapatan Asli Daerah (PAD)

$X_{2}=$ Dana Perimbangan

$\varepsilon \quad=$ Tingkat Kesalahan Pengganggu (standar error)

\section{HASIL DAN PEMBAHASAN}

Analisis statistik deskriptif digunakan untuk menganalisis data seperti nilai minimum, nilai maksimum, nilai rata-rata, dan standard deviation dari masingmasing variabel yang digunakan dalam penelitian ini. Berdasarkan perhitungan yang telah dilakukan, hasil analisis statistik deskriptif dapat dilihat pada Tabel 2.

Tabel 2.

Hasil Analisis Statistik Deskriptif

\begin{tabular}{|c|c|c|c|c|c|}
\hline & $\mathbf{N}$ & Minimum & Maximum & Mean & Std. Deviation \\
\hline PAD & 20 & 183295007 & 3563589483 & 1010640020.45 & 1052021599.52 \\
\hline Dana Perimbangan & 20 & 332251562 & 1102265093 & 672522411.65 & 181986516.86 \\
\hline Kinerja Keuangan & 20 & 3.38 & 41.49 & 15.1840 & 8.2835 \\
\hline Valid N (listwise) & 20 & & & & \\
\hline
\end{tabular}

Tabel 2 menunjukkan bahwa jumlah data yang digunakan dalam penelitian ini adalah 20 sampel data yang terdiri 4 kabupaten/kota dikalikan dengan periode penelitian selama 5 tahun. Berdasarkan Tabel 2 maka diperoleh hasil bahwa nilai rata-rata (mean) dari Pendapatan Asli Daerah (PAD) sebesar Rp 
1.010.640.020.000,45 dengan standar deviasi sebesar 1.052.021.599.000,52. Nilai terendah (minimum) dari PAD adalah sebesar Rp 183.295.007.000,00 yang dimiliki oleh Kabupaten Tabanan pada tahun 2012, sedangkan nilai tertinggi (maksimum) dari PAD adalah sebesar Rp 3.563.589.438.000,00yang dimiliki oleh Kabupaten Badung pada tahun 2016.

Nilai rata-rata (mean) dari dana perimbangan sebesar Rp 672.522.411.000,65 dengan standar deviasi sebesar 181.986.516.000,86. Nilai terendah (minimum) dari dana perimbangan adalah sebesar Rp 332.251.562.000,00 yang dimiliki oleh Kabupaten Badung pada tahun 2015, sedangkan nilai tertinggi (maksimum) dari dana perimbangan adalah sebesar Rp 1.102.265.093.000,00 yang dimiliki oleh Kabupaten Tabanan pada tahun 2016.

Nilai rata-rata (mean) dari kinerja keuangan sebesar 15,1840 persen dengan standar deviasi sebesar 8,2835. Nilai terendah (minimum) dari kinerja keuangan adalah sebesar 3,38 persen yang dimiliki oleh Kota Denpasar pada tahun 2016, sedangkan nilai tertinggi (maksimum) dari kinerja keuangan adalah sebesar 41,49 persen yang dimiliki oleh Kabupaten Badung pada tahun 2012.

Analisis regresi linier berganda dilakukan untuk mengetahui pengaruh lebih dari satu variabel bebas terhadap variabel terikat. Berdasarkan perhitungan yang telah dilakukan, hasil analisis regresi linier berganda dapat dilihat pada Tabel 3

Tabel 3.

Hasil Analisis Regresi Linier Berganda

\begin{tabular}{lccccc}
\hline \multicolumn{1}{c}{ Model } & \multicolumn{2}{c}{$\begin{array}{c}\text { Unstandardized } \\
\text { Coefficients } \\
\text { Std. Error }\end{array}$} & $\begin{array}{c}\text { Standardized } \\
\text { Coefficients } \\
\text { Beta }\end{array}$ & t & Sig. \\
\hline (Constant) & 27.873 & 7.006 & & 3.978 & .001 \\
PAD & -.226 & .081 & .653 & -2.779 & .013 \\
Dana Perimbangan & -1.014 & .288 & -.828 & -3.523 & .003 \\
\hline Sumber: Data diolah, 2018 & & & & &
\end{tabular}


Ni Kadek Novia Indrawati Putridan Ni Putu Ayu Darmayanti, Pengaruh PAD dan..

Berdasarkan Tabel 3, persamaan regresi linier berganda penelitian ini dapat dirumuskan sebagai berikut:

$$
\mathrm{Y}=27,873-0,226 \mathrm{X}_{1}-1,014 \mathrm{X}_{2}
$$

Keterangan:

$\mathrm{Y} \quad=$ Kinerja Keuangan Pemerintah Daerah

$\mathrm{X}_{1} \quad=$ Pendapatan Asli Daerah

$\mathrm{X}_{2} \quad=$ Dana Perimbangan

$\varepsilon \quad=$ Tingkat kesalahan pengganggu (standar eror)

Persamaan regresi linier berganda di atas menunjukkan arah dari masingmasing pengaruh variabel bebas terhadap variabel terikat, dimana koefisien regresi dari variabel bebas yang bertanda positif berarti memiliki pengaruh yang searah terhadap variabel terikat sedangkan jika koefisien regresi dari variabel bebas bertanda negatif berarti memiliki pengaruh yang berlawanan arah terhadap variabel terikat. Berdasarkan persamaan regresi linier berganda di atas, maka dapat dijelaskan bahwa nilai konstanta sebesar 27,873 menunjukkan bahwa apabila pendapatan asli daerah dan dana perimbangan dianggap konstan menyebabkan kinerja keuangan pemerintah daerah meningkat sebesar 27,873 persen.

Nilai koefisien regresi PAD sebesar -0,226 menunjukkan bahwa apabila PAD meningkat sebesar satu satuan menyebabkan kinerja keuangan pemerintah daerah menurun sebesar 0,226 satuan dengan anggapan bahwa variabel lainnya konstan.

Nilai koefisien regresi dana perimbangan sebesar -1,014 menunjukkan bahwa apabila dana perimbangan meningkat sebesar satu satuan menyebabkan 
kinerja keuangan pemerintah daerah menurun sebesar 1,014 satuan dengan anggapan bahwa variabel lainnya konstan.

Pengujian kelayakan model (Uji F) digunakan untuk mengetahui seberapa jauh kemampuan variabel independen mempengaruhi variabel dependen secara bersama-sama (simultan). Pengujian dilakukan dengan significance level 0,05 ( $\alpha=$ 5\%). Hasil uji F dapat dilihat pada Tabel 4.

Tabel 4.

Hasil Uji Kelayakan Model (Uji F)

\begin{tabular}{lccccc}
\hline \multicolumn{1}{c}{ Model } & Sum of Squares & Df & Mean Square & F & Sig. \\
\hline Regression & .684 & 2 & .342 & 6.470 & $.008^{\mathrm{a}}$ \\
Residual & .898 & 17 & .053 & & \\
Total & 1.582 & 19 & & & \\
\hline
\end{tabular}

Sumber: Data diolah, 2018

Hasil uji F pada Tabel 4mempunyai F-hitung sebesar 6,470 dengan nilai signifikansi 0,008 . Tarif nyata $\alpha=5 \%$ atau keyakinan $95 \%$ dengan derajat kebebasan pembilang $(\mathrm{k}-1)=(3-1)$, derajat kebebasan penyebut $(n-k)=(20-3)$ diperoleh hasil $(2,17)$, maka $F_{\text {tabel }}=3,59$. Hasil uji menunjukkan $F_{\text {hitung }}(6,470)>$ $F_{\text {tabel }}(3,58)$ dan Sig. Uji F $(0008)<\alpha(0,05)$ maka berada pada daerah penolakan $\mathrm{H}_{0}$ dan penerimaan $\mathrm{H}_{1}$. Hal ini berarti terdapat pengaruh yang signifikan antara semua variabel independen terhadap variabel dependen sehinga model layak digunakan untuk memprediksi.

Uji parsial atau uji t merupakan uji yang digunakan untuk mengetahui pengaruh masing-masing variabel bebas terhadap variabel terikat secara parsial. Pada penelitian ini, variabel bebas akan berpengaruh signifikan terhadap variabel terikat apabila masing-masing koefisien signifikan dari variabel bebas memiliki nilai lebih kecil dari taraf signifikansi yaitu sebesar 5\% $(0,05)$. Hasil pengujian 
Ni Kadek Novia Indrawati Putridan Ni Putu Ayu Darmayanti, Pengaruh PAD dan..

parsial dapat dilihat pada Tabel 3 (analisis regresi linier berganda) sehingga dapat disimpulkan bahwa hasil dari variabel independen yaitu pendapatan asli daerah adalah sebesar 0,013 yang lebih kecil dari taraf signifikansi yaitu sebesar 0,05. Hasil analisis ini memberikan arti bahwa pendapatan asli daerah berpengaruh signifikan terhadap kinerja keuangan pemerintah daerah. Nilai koefisien regresi pendapatan asli daerah sebesar -0,226 menunjukkan adanya pengaruh negatif antara pendapatan asli daerah terhadap kinerja keuangan pemerintah daerah. Berdasarkan hasil analisis, dapat disimpulkan bahwa pendapatan asli daerah berpengaruh negatif signifikan terhadap kinerja keuangan pemerintah daerah, sehingga hipotesis pertama yaitu Pendapatan Asli Daerah (PAD) berpengaruh positif signifikan terhadap kinerja keuangan pemerintah daerah ditolak.

Hasil analisis regresi linier berganda menunjukkan bahwa nilai signifikansi dari variabel independen dana perimbangan adalah sebesar 0,003 yang lebih kecil dari taraf signifikansi yaitu sebesar 0,05. Hasil analisis ini memberikan arti bahwa dana perimbangan berpengaruh signifikan terhadap kinerja keuangan pemerintah daerah. Nilai koefisien regresi dana perimbangan sebesar -1,014 menunjukkan adanya pengaruh negatif antara dana perimbangan terhadap kinerja keuangan pemerintah daerah. Berdasarkan hasil analisis, dapat disimpulkan bahwa dana perimbangan berpengaruh negatif signifikan terhadap kinerja keuangan pemerintah daerah, sehingga hipotesis kedua yaitu dana perimbangan berpengaruh negatif signifikan terhadap kinerja keuangan pemerintah daerah diterima.

Hasil penelitian ini menunjukkan bahwa PAD berpengaruh negatif signifikan terhadap kinerja keuangan pemerintah daerah kabupaten/kota di 
wilayah Sarbagita Provinsi Bali tahun 2012-2016. PAD merupakan sumber pendapatan utama pemerintah daerah yang diperolah dari sumber-sumber di dalam daerah itu sendiri yang dipungut berdasarkan peraturan daerah sesuai perundang-undangan yang berlaku. PAD yang tinggi menunjukkan tingginya tingkat kemampuan sumber daya keuangan suatu daerah yang nantinya akan digunakan sebagai modal dasar pemerintah daerah dalam membiayai pembangunan dan untuk memperkecil ketergantungan dana dari pemerintah pusat.

Hasil penelitian ini yang menunjukkan adanya pengaruh negatif signifikan antara PAD terhadap kinerja keuangan pemerintah daerah bermakna bahwa perolehan kekayaan daerah berupa PAD oleh pemerintah daerah belum optimal sehingga tidak serta merta dapat meningkatkan kinerja keuangan pemerintah daerah tersebut. Di wilayah Sarbagita sendiri, rata-rata kontribusi PAD terhadap total pendapatan selama tahun 2012-2016 tidak mencapai setengah dari total pendapatan, yaitu sebesar 41,545 persen, maka dapat dikatakan bahwa kemampuan pemerintah daerah dalam pelaksanaan desentralisasi untuk meningkatkan kinerja keuangannya masih kurang sehingga pemerintah daerah tersebut dapat dikatakan belum mampu untuk menggali potensi-potensi daerah guna memperoleh PAD yang lebih besar.

PAD terbesar di wilayah Sarbagita diperoleh dari hasil pajak daerah dan hasil retribusi daerah. Data realisasi Anggaran Pendapatan dan Belanja Daerah (APBD)wilayah Sarbagita tahun 2012-2016 menunjukkan bahwa perolehan pendapatan yang bersumber dari hasil pajak daerah jauh lebih besar dari hasil retribusi daerah. Ketergantungan pemerintah daerah terhadap hasil pajak daerah 
Ni Kadek Novia Indrawati Putridan Ni Putu Ayu Darmayanti, Pengaruh PAD dan..

saja belum cukup untuk membiayai seluruh kegiatan pemerintahan, sehingga pemerintah daerah akan terus bergantung dari sumber pendanaan yang bukan hasil dari pengelolaan kekayaan daerah. Pengelolaan yang kurang baik akan mempengaruhi sumber pendapatan bagi daerah sehingga dapat menurunkan kinerja keuangan pemerintah daerah tersebut.

Pengaruh negatif yang dihasilkan dalam penelitian ini juga mendukung hasil penelitian Wiguna (2015) yang mengemukakan bahwa PAD berpengaruh negatif signifikan terhadap kinerja keuangan pemerintah daerah. Selain itu, Armaja et al. (2015), serta Mulyani dan Wibowo (2017) juga membuktikan hasil yang sama dimana variabel PAD berpengaruh negatif terhadap kinerja keuangan pemerintah daerah.

Hasil penelitian ini menunjukkan bahwa dana perimbangan berpengaruh negatif signifikan terhadap kinerja keuangan pemerintah daerah kabupaten/kota di wilayah Sarbagita Provinsi Bali tahun 2012-2016. Dana Perimbangan yang meliputi dana bagi hasil pajak dan bukan pajak serta Dana Alokasi Umum (DAU) dan Dana Alokasi Khusus (DAK) merupakan dana transfer yang diberikan dari pemerintah pusat kepada pemeritah daerah dengan tujuan untuk membiayai kelebihan belanja daerah. Defisit akan terjadi apabila realisasi belanja daerah lebih tinggi daripada pendapatan daerah sehingga untuk menutup kekurangan belanja daerah, maka pemerintah pusat mentransfer dana dalam bentuk dana perimbangan kepada pemerintah daerah.

Hasil penelitian ini yang menunjukkan adanya pengaruh negatif signifikan antara dana perimbangan terhadap kinerja keuangan pemerintah daerah 
mengindikasikan bahwa semakin besar dana perimbangan yang diterima pemerintah daerah dari pemerintah pusat maka dapat mencerminkan ketergantungan daerah tersebut terhadap pemerintah pusat untuk memenuhi kebutuhan daerahnya semakin besar sehingga kemampuan daerah tersebut dalam menggali potensi dari daerahnya sendiri semakin rendah. Di wilayah Sarbagita sendiri, rata-rata penerimaan dana perimbangan terhadap total pendapatan selama tahun 2012-2016 hampir mencapai setengah dari total pendapatan, yaitu sebesar 41,557 persen. Hal tersebut menjelaskan bahwa semakin besar dana perimbangan yang diterima akan membuat kinerja keuangan pemerintah daerah tersebut menurun.

Besar kecilnya penerimaan dana perimbangan sangat mempengaruhi kinerja keuangan. Ketergantungan pemerintah daerah terhadap dana perimbangan yang tinggi menjadikan daerah tersebut tidak memiliki kewenangan dan kebebasan dalam hal penggunaan sumber pendapatan sehingga prinsip otonomi daerah akan sulit tercapai jika pemerintah daerah masih bergantung pada dana perimbangan. Menurut Mardiasmo (2004:155), yang harus di pahami adalah bahwa kewenangan yang dimiliki daerah tidak sebatas dalam menggunakan PAD saja, tetapi juga kewenangan dalam penggunaan dana perimbangan.

Hasil penelitian ini sejalan dengan hasil penelitian yang dilakukan Andirfa et al. (2016)yang mengemukakan bahwa semakin besar transfer dana perimbangan akan memperlihatkan semakin kuat pemerintah daerah bergantung pada pemerintah pusat sehingga akan membuat kinerja keuangan pemerintah daerah menurun. Pengaruh negatif yang dihasilkan penelitian ini juga mendukung 
Ni Kadek Novia Indrawati Putridan Ni Putu Ayu Darmayanti, Pengaruh PAD dan..

hasil penelitian Wahyuningsih (2016) yang membuktikan bahwa dana perimbangan berpengaruh negatif terhadap kinerja keuangan pemerintah Kabupaten/Kota di Provinsi Jawa Tengah. Armaja et al. (2015), Indriani dan Sastradipraja (2014), serta Budianti dan Alexander (2016) dalam penelitiannya juga membuktikan hasil yang sama dimana variabel dana perimbangan berpengaruh negatif terhadap kinerja keuangan pemerintah daerah.

PAD merupakan pendapatan yang terdiri dari pajak daerah, retribusi daerah, hasil pengelolaan kekayaan daerah, dan lain lain PAD yang sah yang dipungut berdasarkan peraturan perundang-undangan. Hasil penelitian ini menunjukkan bahwa pendapatan asli daerah berpengaruh negatif signifikan terhadap kinerja keuangan pemerintah daerah kabupaten/kota di wilayah Sarbagita Provinsi Bali tahun 2012-2016. Hasil penelitian ini mengindikasikan implikasi bahwa pemerintah daerah dengan PAD yang tinggi seharusnya diikuti dengan kinerja keuangan yang tinggi pula. Pemerintah daerah dengan PAD tinggi tetapi tidak diikuti dengan kinerja keuangan pemerintah yang baik maka pemerintah daerah tersebut diharapkan untuk melakukan perbaikan ke depannya. Pemerintah daerah harus lebih menggali dan melihat sumber daya yang dimiliki untuk perbaikan kinerja keuangan pemerintah daerahnya, sehingga bukan hanya satu pendapatan saja yang digali, tetapi semua potensi daerah untuk memperoleh pendapat dapat dioptimalkan pengelolannya.

Dana perimbangan merupakan salah satu sumber pendanaan daerah yang meliputi dana bagi hasil pajak dan bukan pajak serta Dana Alokasi Umum (DAU) dan Dana Alokasi Khusus (DAK). Hasil penelitian ini menunjukkan bahwa dana 
perimbangan berpengaruh negatif signifikan terhadap kinerja keuangan pemerintah daerah kabupaten/kota di wilayah Sarbagita Provinsi Bali tahun 20122016. Hasil penelitian ini mengindikasikan implikasi bahwa pemerintah daerah dalam penggunaan dana perimbangan diharapkan dapat dilaksanakan sesuai dengan tujuan yang di harapkan. Semakin besar penerimaan dana yang diperoleh maka akan mempengaruhi kinerja keuangan. Pemerintah daerah perlu mengurangi penerimaan dana perimbangan dengan lebih meningkatkan pendapatan dari dalam daerahnya, sehingga dengan penerimaan dana perimbangan yang kecil pemerintah daerah dikatakan mampu untuk membiayai segala kebutuhan pemerintahannya dan nantinya dapat meningkatkan kinerja keuangan pemerintah daerah.

\section{SIMPULAN}

Pendapatan asli daerah menunjukkan adanya pengaruh negatif signifikan terhadap kinerja keuangan pemerintah Kabupaten/Kota di wilayah Sarbagita Provinsi Bali tahun 2012-2016 yang bermakna bahwa penerimaan kekayaan daerah berupa PAD oleh pemerintah daerah tidak serta merta dapat meningkatkan kinerja keuangan pemerintah daerah tersebut. Penerimaan PAD yang tinggi seharusnya diikuti dengan kinerja keuangan pemerintah yang baik.

Dana perimbangan menunjukkan adanya pengaruh negatif signifikan terhadap kinerja keuangan pemerintah daerah Kabupaten/Kota di wilayah Sarbagita Provinsi Bali tahun 2012-2016 yang mengindikasikan bahwa semakin besar dana perimbangan yang diterima pemerintah daerah dari pemerintah pusat maka dapat mencerminkan semakin besar ketergantungan daerah tersebut terhadap pemerintah pusat untuk memenuhi kebutuhan daerahnya sehingga 
Ni Kadek Novia Indrawati Putridan Ni Putu Ayu Darmayanti, Pengaruh PAD dan..

kemampuan daerah tersebut dalam menggali potensi dari daerahnya sendiri semakin rendah. Hal tersebut menjelaskan bahwa semakin besar dana perimbangan yang diterima akan membuat kinerja keuangan pemerintah daerah tersebut menurun.

Bagi pemerintah daerah, kemampuan dalam meningkatkan PAD perlu ditingkatkan kembali, terutama PAD yang berasal dari retribusi daerah sehingga dapat meningkatkan penerimaan daerah dan meminimalkan ketergantungan daerah terhadap bantuan dari pemerintah pusat sehingga pemerintah daerah mampu membiayai sendiri segala kegiatan daerahnya. Pemerintah daerah akan memiliki kinerja yang baik dalam mengelola keuangan daerahnya apabilakemampuan pemerintah daerah dalam membiayai sendiri segala kegiatan daerahnya meningkat. Meningkatnya PAD akan mengurangi penerimaan dana perimbangan. Dana perimbangan yang tinggi mengdindikasikan bahwa pemerintah daerah masih bergantung dengan dana bantuan yang diberikan pemerintah pusat untuk memenuhi kebutuhan pemerintahannya sehingga kinerja keuangan pemerintah daerah akan menurun.

Bagi peneliti selanjutnya disarankan menggunakan rasio-rasio lainnya untuk mengukur kinerja keuangan pemerintah daerah seperti rasio kemandirian keuangan pemerintah daerah, rasio efisiensi dan rasio efektivitas. Peneliti selanjutnya juga diharapkan untuk menambah periode penelitian serta lokasi penelitian. Selain itu, komponen-komponen dalam pendapatan asli daerah dan dana perimbangan juga dapat dijadikan variabel penelitian selanjutnya.

\section{REFERENSI}


Alfarisi, H. Salman. (2015). Pengaruh Pajak Daerah, Retribusi Daerah, dan Dana Perimbangan terhadap Kinerja Keuangan Pemerintah Daerah (Studi Empiris pada Kabupaten dan Kota di Provinsi Sumatera Barat. E-jurnal Universitas Negeri Padang, 3 (1), hal.1-23.

Andirfa,Mulia, Hasan Basri, M.Shabri A.Majid. (2016). Pengaruh Belanja Modal, Dana Perimbangan, dan Pendapatan Asli Daerah terhadap Kinerja Keuangan Kabupaten dan Kota di Provinsi Aceh. Jurnal Magister Akuntansi Pascasarjana Universitas Syiah Kuala, 5 (3), hal.30-38.

Antari, Ni Putu Gina Sukma dan Sedana, Ida Bagus Panji. (2018). Pengaruh Pendapatan Asli Daerah dan Belanja Modal terhadap Kinerja Keuangan Pemerintah Daerah. E-Jurnal Manajemen Unud, 7 (2), hal.1080-1110.

Armaja, Ridwan Ibrahim, Aliamin. (2015). Pengaruh Kekayaan Daerah, Dana Perimbangan, dan Belanja Daerah terhadap Kinerja Keuangan (Studi Pada Kabupaten/Kota Di Aceh). Jurnal Perspektif Ekonomi Darussalam, 3 (2), hal.168-181.

Aziz, Asmaul. (2016). Pengaruh Karakteristik Pemerintah Daerah terhadap Kinerja Kinerja Keuangan Pemerintah Daerah (Studi pada Pemerintah Daerah Kabupaten/Kota di Jawa Timur). E-journal STIE Dewantara. 11 (1), hal. 86-101.

Badan Pusat Statistik. (2017). Statistik Keuangan Pemerintah Kabupaten/Kota SeProvins Bali Tahun 2012-2016. Denpasar: BPS Bali.

-----. 2017. Provinsi Bali Dalam Angka 2017. Denpasar: BPS Bali.

Budianto dan Alexander, Stanly W. (2016). Pengaruh PAD dan Dana Perimbangan terhadap Kinerja Keuangan Pemerintah Kabupaten/Kota Di Provinsi Sulawesi Utara.Jurnal EMBA, 4 (4), hal. 844-851.

Darwanis dan Saputra, Ryanda. (2014). Pengaruh Belanja Modal terhadap Pendapatan Asli Daerah dan Dampaknya pada Kinerja Keuangan Pemerintah Daerah (Studi Empiris pada Pemerintah Daerah Kabupaten/Kota di Provinsi Aceh). Jurnal Dinamika Akuntansi dan Bisnis, 1 (2), hal. 183-199.

Erawati, Ni Made Adi. (2012). Analisis Kinerja Kawasan Metropolitan Sarbagita. Jurnal Akuntansi , Fakultas Ekonomi Universitas Udayana, 7 (1), hal. 119.

Indriani, Diah dan Sastradipraja, Usman. (2014). Pengaruh Pendapatan Asli Daerah, Dana Perimbangan, dan Lain-Lain Pendapatan Daerah yang Sah terhadap Kinerja Keuangan Pemerintah Daerah (Studi pada Pemerintah 
Ni Kadek Novia Indrawati Putridan Ni Putu Ayu Darmayanti, Pengaruh PAD dan..

Daerah Cirebon Tahun Anggaran 2008-2012). Portofolio, 11 (1), hal. 55-76.

Kamaroellah, R. Agoes. (2017). Analisis Tingkat Kemampuan Keuangan Daerah dalam Mendukung Pelaksanaan Otonomi Daerah. Nuansa. Volume 14, No. 1 Januari - Juni 2017.

Mahmudi. (2010). Manajemen Keuangan Daerah. Jakarta: Erlangga.

Mardianta, Anthoni Veery, B. Kombaitan, Heru Purboyo, Delik Hudalah. (2016). Pengelolaan Kawasan Metropolitan di Indonesia dalam Perspektif Peraturan Perundangan. Prosiding Temu Ilmiah IPLBI, 27 Oktober 2016. C: 051-056.

Mardiasmo. (2004). Otonomi dan Manajemen Keuangan Daerah. Yogyakarta: PenerbitAndi.

Mokodompit, Paramitha Sandy, Sifrid S. Pangemanan, Inggriani Elim. (2014). Analisis Kinerja Keuangan Pemerintah Daerah Kota Kotamobagu.Jurnal EMBA 1521, 2 (2), hal. 1521-1527.

Mulyani, Sri, dan Wibowo, Hardiyanto. (2017). Pengaruh Belanja Modal, Ukuran Pemerintah Daerah, Intergovernmental Revenue, dan Pendapatan Asli Daerah terhadap Kinerja Keuangan (Kabupaten/ Kota di Provinsi Jawa Tengah,Tahun 2012-2015).Kompartemen. Vol. XV No.1, Maret 2017.

Peraturan Menteri Dalam Negeri Republik Indonesia Nomor 13 Tahun 2006 Pedoman Pengelolaan Keuangan Daerah. 15 Mei 2006. Jakarta.

Peraturan Pemerintah Republik Indonesia Nomor 58 Tahun 2005 Pengelolaan Keuangan Daerah. 9 Desember 2005. Lembaran Negara Republik Indonesia Tahun 2005 Nomor 140. Jakarta.

Peraturan Pemerintah Republik Indonesia Nomor 105 Tahun 2000 Pengelolaan dan Pertanggungjawaban Keuangan Daerah. 10 November 2000. Lembaran Negara Republik Indonesia Tahun 2000 Nomor 202. Jakarta.

Peraturan Presiden Nomor 45 Tahun 2011 Rencana Tatat Ruang Kawasan Perkotaan Denpasar, Badung, Gianyar, dan Tabanan. 27 Juli 2011. Jakarta.

Saputra, Sandy Candra, I Wayan Suwendra, Fridayana Yudiaatmaja. (2016). Analisis Kinerja Keuangan Pemerintah Daerah dalam Pengelolaan Anggaran Pendapatan dan Belanja Daerah di Kabupaten Jembrana Tahun 2010 - 2014. E-Journal Bisma Universitas Pendidikan Ganesha Jurusan Manajemen, 4 (1), hal. 1-11. 
Simanullang, Gideon. (2013). Pengaruh Belanja Modal, Intergovernmental Revenue, dan Pendapatan Asli Daerah terhadap Kinerja Keuangan Daerah Kota dan Kabupaten di Provinsi Kepulauan Riau Tahun 20082012. Umrah Journal of Accounting, 1 (1), hal 1-24.

Taras, Tyasani dan Artini, Luh Gede Sri. (2017). Analisis Pendapatan Asli Daerah (PAD) dalam Upaya Pelaksanaan Otonomi Daerah di Kabupaten Badung Bali. E-Jurnal Manajemen Unud, 6 (5), hal. 2360:2387.

Undang-undang Republik Indonesia Nomor 22 Tahun 1999 Pemerintah Daerah. 7 Mei 1999. Lembar Negara Republik Indonesia Tahun 1999 Nomor 60. Jakarta.

Undang-undang Republik Indonesia Nomor 25 Tahun 1999 Perimbangan Keuangan Antara Pemerintah Pusat dan Daerah. 19 Mei 1999. Lembar Negara Republik Indonesia Tahun 1999 Nomor 72. Jakarta.

Undang-undang Republik Indonesia Nomor 32 tahun 2004 Pemerintah Daerah. 15 Oktober 2004. Lembar Negara Republik Indonesia Tahun 2004 Nomor 125. Jakarta.

Undang-undang Republik Indonesia Nomor 34 Tahun 2000 Pajak Daerah dan Retribusi Daerah. 20 Desember 2000. Lembar Negara Republik Indonesia Tahun 2000 Nomor 246. Jakarta.

Undang-undang Republik Indonesia Nomor 33 tahun 2004 Perimbangan Keuangan Antara Pemerintah Pusat dan Pemerintah Daerah. 15 Oktober 2004. Lembar Negara Republik Indonesia Tahun 2004 Nomor 126. Jakarta.

Wahyuningsih, Yoshinta Endah. (2016). Pengaruh Pendapatan Asli Daerah (PAD) dan Dana Perimbangan terhadap Kinerja Keuangan Pemerintah Kabupaten/Kota di Provinsi Jawa Tengah. Jurnal Fakultas Ekonomi Dan Bisnis Universitas Muhammadiyah Surakarta, 1 (1), hal 1-17.

Wiguna, Kusnadi Yudha. (2015). Pengaruh Pendapatan Asli Daerah, Dana Alokasi Umum, dan Belanja Modal Pemerintah Daerah Terhadap Kinerja Keuangan Pemerintah Daerah Kabupaten/Kota di Sumatera Selatan. Jurnal Fordema, 12 (1), hal. 38-50.

Yanto, Febri Ferta, Mukhlizul Hamdi, Meihendri. (2015). Pengaruh Pendapatan Asli Daerah (Pad) dan Dana Perimbangan terhadap Kinerja Keuangan Pemerintah Kabupaten dan Kota di Provinsi Sumbar. E-jurnal Jurusan Akuntansi, Fakultas Ekonomi, Universitas Bung Hatta, 7 (1), hal. 1-11. 